AÜiFD XLVI (2005), sayı II, s. 43-54

\title{
Türk Kelâmcıları İbn Kemâl (1468-1534) ve Mustafa Sabri'de (1860-1954) Kader Problemi ve Anlambilim Açısından Bir Değerlendirme
}

H.SABRI ERDEM

Doç. Dr., ANKARA Ü. İLÂHIYAT FAKÜLTESI

e-mail:erdem@divinity.ankara.edu.tr

\begin{abstract}
The Problem of Predestination in Turkish theologians Ibn Kemal (1468-1534)and Mustafa Sabri (1860-1954) and A Consideration ofSemantics.Ibn Kemal and Mustafa Sabri solved the problem of predestination according to their theological methods. whichhas the abstract character of rationalism. This caused some negative implications. For the classical solutions are not functional for our theological problems and havesome negative implications, semantic methodmaybe used instead.
\end{abstract}

\section{keywords}

Predestination, Ibn Kemal, Mustafa Sabri, Semantic Method, Islamic Theology.

Bu yazımızda kader problemini Türk kelâmcıları İbn Kemâl ve Mustafa Sabri açısından kısaca ele alıp ortaya çıkan birtakım olumsuzluklara değindikten sonra günümüz kelâmının bir metodu olmasını önerdiğimiz anlambilim açısından yeni bir çözüm denemesinde bulunmaya çalışacağız. Bu vesileyle de dilbilimsel semantik ile felsefî semantik arasındaki ayırıma yani anlambilim anlayışımıza kısaca değinmiş olacağız.

İbn Kemâl'e göre İslâm'da ne cebir ne de tefviz (fiilleri kula havale etme) anlayışı vardır. Cebir anlayışından söz edemeyiz. Zira kul, iyilikleri kazanmada ve kötülüklerden uzaklaşmada hürdür (muhtardır). Allah'ın âdeti, kulun seçiminin (ihtiyarının) akabinde kulun fiilini yaratmasıdır. İslâm'da tefviz anlayışından da söz edilemez. Zira kulun seçiminin menşei kalpte meydana gelen bir sebeptir (daîdir). Kalpte meydana gelen sebepler de Allah'ın meşiyyetine ve iradesine tâbidir. Kulun Allah'ın meşiyyetine ve iradesine herhangi bir müdahaleden bahsedilemez. Kur'an'da bu duruma şu ayetle 
dikkat çekilir: "Allah dilemedikçe siz dilemezsiniz." Ancak meselenin bu şekilde ele alınmasıyla çözümü zor bir durumla karşı karşıya kalmaktayız. Zira bir taraftan kulun seçiminden bahsedilmekte diğer taraftan da kulun seçimi Allah'ın meşiyyetine ve iradesine tâbi kılınmaktadır. Dolayısıyla kulun seçimi söz konusu olduğunda bu seçimin Allah'ın meşiyyetine ve iradesine tâbi olması zor olduğu gibi, Allah'ın meşiyyeti ve iradesi söz konusu olduğunda da kulun seçiminden bahsetmek zordur.

Allah'ın ilim ve takdirinin kulun hürriyetini engellemediğine dair yazar, şöyle bir örnek verir: Meselâ Ebû Cehl'in imanı mümkündür. Ebû Cehl'in imanının yokluğu Allah'ın ilmi ve takdiri sebebiyle mümkün olmaktan çımaz. Zira zatî imkânın zatî imkânsıza dönüşmesi imkânsızdır (muhaldir). ${ }^{2}$ Yazar burada Allah'ın ilminin ve takdirinin, Ebû Cehl'in imanının yokluğunda tesiri olmadığını söylemek istiyor. Bunun gerekçesi olarak da zatî imkânın zatî imkânsıza dönüşmesinin mümkün olmaması durumu ifade ediliyor. Halbuki Allah'ın ilminin ve takdirinin, Ebû Cehl'in imanının olmamasında herhangi bir tesirinin olmadığını ifade etmek için böyle bir gerekçeye ihtiyaç yoktur. Zira Allah'ın ilmi ve takdiri sebebiyle zatî imkânın zatî imkânsıza dönüşmesi gibi bir durumun gerçekleşmesi söz konusu olmayıp, sadece mümkün olan Ebû Cehl'in imanının yokluğunun gerçekleşmesi söz konusu olabilir. Dolayısıyla yazarın sözünü ettiği durumun gerekçe olması söz konusu olmadığından buna bağlı olarak Allah'ın ilminin ve takdirinin Ebû Cehl'in imanının yokluğunu imkân dairesinden çıkarıp çıkarmaması durumu da zaten söz konusu olmayacaktır.

İbn Kemâl, Ebû Cehl'in iman etmesi, Allah'ın ilminden ve Ebû Cehl'in küfür üzere ölümünü takdirinden sonra Allah'ın kudretinde olmazsa, Allah'a acziyet gerekir demektedir. ${ }^{3}$ Ancak bu problemli bir ifadedir. Zira böyle bir ifade Ebû Cehl'in hem imanının hem de imanının yokluğunun, Allah'ın kudretinde olduğunu söylemek demektir. Bu ise takdire zıttır. Çünkü takdir tek ve belirli bir durumu ifade eder, imkânı değil.

Yazara göre iki türlü takdir ve iki türlü levha vardır. Kevn (oluş) âleminde hâdis olan her şeyin levh-i mahfuzda icmalî bir sureti vardır. Bu, Kur'an'da ummu kitap diye tabir olunur. Bu kitabın zamandan mücerret oluşuna ayetteki "indehu"ibaresi ile işaret olunur. Ayrıca kevn âleminde hadis olan her şeyin ilâhî hikmetin gerektirdiğine uygun olarak mahv ve

1 İbn Kemâl, Risalefi'l-kadai ve'l-kader, 1310, s. 63.

2 A.g.e., s. 36.

3 A.y. 
ispat levhasında tafsilî bir sureti vardır. Bu levha da Kur'an'da 'dünya seması' diye tabir olunur. Her iki levhaya da Ra'd Sûresi 39. ayette işaret olunmaktadır. Bu durumda birinci takdirde değil ama ikinci takdirde değişiklik söz konusu olabilir. ${ }^{4}$ Ancak bu şekilde ikili bir takdir ve levha anlayışı problem doğurur. Zira takdirin takdir olması için onda değişimin olmamas1 gerekir. Ayrıca söz konusu ayet, takdirle ilgili değildir. Ayetin bağlamını göz önüne aldığımızda, Allah'ın dilediğini silmesinin ve dilediğini tespit etmesinin ve ummu kitabın O'nun katında olmasının, Allah'ın zaman zaman peygamberler ve onlarla birlikte kitaplar göndermesiyle ilgili olduğunu görürüz. Yani Allah, zaman zaman peygamberler ve onlarla birlikte vahiy göndermiş ve bu vahiyden dilediğini silip dilediğini de sabit bırakmıştır. Dolayısıyla yazarın söz konusu ayeti ikili takdir anlayışına delil olarak kullanması bir yorum olmaktadır.

Keza İbn Kemâl, bir hadisle ilgili olarak yapılan bir itiraza verdiği cevapla ikili takdir anlayışına uygun bir yorum yapar. İtiraza göre saîd olan kimse annesinin karnında saîd, şakî olan kimse de annesinin karnında şakî olduğundan saîdin saadeti tahsilinde ihtiyarı olmadığı gibi, şakînin de şekâveti değiştirmesinde gücü ve kudreti yoktur. Böyle bir itiraza verilen cevapta saîdin saadeti şakînin de şekâveti annesinin karnındayken takdir edildiğinden söz konusu kimse için şekâvetin doğmadan önce takdir edilmesinin o'nu saadeti kabul etme kabiliyetinden çıkarmadığı gibi, yine söz konusu kimse için saadetin doğmadan önce takdir edilmesinin de o'nu zorunlu olarak saadete sokmadığ 1 ifade ediliyor. ${ }^{5}$ Görüldügüü gibi yazar, ikili takdir anlayışına göre hadisi yorumlamıştır. Ancak ikili bir takdir anlayışından bahsetmek biraz önce zikrettiğimiz üzere problemli olduğu gibi, hadisteki olayı takdir olarak değerlendirmek de sadece bir yorumdur. Ayrıca yazar, hadisle ilgili olarak yaptığı bu yoruma delil olarak bir başka hadisi kullanır. ${ }^{6} \mathrm{Bu}$ hadiste her doğanın fitrat üzere doğduğundan ve sonradan anne ve babasının o kimseyi yahudi, hıristiyan ve mecusî yaptığından bahsedilir. Ancak bu hadisin yazarın görüşüne delil olarak kullanılmasında problem vardır. Zira hadiste her doğanın fitrat üzere doğduğundan bahsedilmesine karşılık bir önceki hadiste saîdin anne karnında saîd olduğundan şakînin de yine anne karnında şakî olduğundan bahsedilmektedir. Yani hadisler, birbirinden farklı şeyler bahsetmektedirler.

Diğer Türk kelâmcısı Mustafa Sabri de insanın yaptıklarının karşılı̆̆ını dünyada ve ahirette görmesiyle ilgili olarak mesuliyet esasını muhafaza

4 A.g.e., s. 54-55.

5 A.g.e., s. 60

6 A.y. 
etmesi şartıyla cebir anlayışını müdafaa ettiğinden bahseder. ${ }^{7}$ Yani İbn Kemâl'de olduğu gibi Mustafa Sabri de hem mesuliyeti hem de cebir anlayışını kabul etmektedir. Ancak cebir anlayışı ile mesuliyet bağdaştırılabilir mi? Yazar da böyle bir itirazı göz önüne alarak bir şeye mecbur olan kişinin ondan mesul olmaması gerekmezmi sorusuna, biz bu gerekliliği kabul etmeyiz diye cevap verir. Zira biz, insanın kendisi için herhangi bir faydaya, zarara, hayra ve şerre malik olamayacağını bununla birlikte Allah'ın yanında mesul olacağını söylüyoruz. ${ }^{8}$ Ancak bunun söylenmesi çözüm için yeterli olur mu? Ayrıca insanın kendisi için hayra ve şerre malik olamayacağ1nı söylemek, "kim zerre miktarı hayır işlerse onu görür, kim zerre miktarı şer işlerse onu görür" (Zilzal, 99/7-8) ayetlerine zit bir durum oluşturmaz mı?

Hem cebri hem de mesuliyeti kabul eden Mustafa Sabri, Nahl Sûresi 93. ayeti buna delil olarak kullanır.9 Ayetin mânâsı şöyledir: "Allah dileseydi hepinizi tek bir ümmet yapardı. Fakat Allah, dilediğini saptırıp dilediğine hidayet verir. Muhakkak yaptıklarınızdan sorumlu tutulacaksınız."Yazara göre Allah dilediğini saptırıp dilediğine hidayet verir. Dolayısıyla insanın hayrı da şerri de Allah'ın meşiyyetine bağlıdır. Hiçbir şey insanın elinde değildir. Buna rağmen o mesuldür. Ve Allah bu mesuliyeti insana yüklediği için zulmetmiş sayılmaz. Ancak yazar, ayeti bağlamından koparıp kendi görüşü doğrultusunda yorumlayarak delil olarak kullanmaktadır. Zira ayette Allah'ın meşiyyeti insanı saptırmak ve hidayete erdirmekle ilgili olduğu gibi, başka ayetleri de göz önüne alarak insanın hidayeti Allah'tan istemesiyle de ilgilidir denebilir. Yani Allah'ın meşiyyeti insanın fiilleri ile ilgili olmayıp, insanı saptırmak ve hidayete erdirmekle ve hidayetin Allah'tan istenmesiyle ilgili olduğu söylenebilir. Dolayısıyla meseleye bakış tarzı gereği insanın fiillerini Allah'ın irade etmesiyle insanın sorumluluğu ayette birleştiriliyor.

Mustafa Sabri'ye göre insanın Allah'ın meşiyyetine tâbi olması ve mutlak olarak ona muhalif olmaması mânâsında açıklanan cebir, manevî cebir olup, zorlama (ikrah) mânâsındaki cebre benzemez. Manevî cebir, kulların muhtariyetine mani olmadığı gibi, baskı ve zorlama olmaksızın hatta kulunu ikna ve razı etme yoluyla, süsleme ve sevdirme yoluyla kulunun iradesini ilgili olduğu şeye meylettirir. Dolayısıyla insan da iradesine ve kanaatine göre iş yapmış olur. Bu durumda insan, cebir altında olmadığı gibi mesul olmaktan da çıkmış değildir. ${ }^{10}$ Ancak burada problemli bir durum söz konusudur. Zira Allah'ın iradesi kulunda ona baskı ve zorlama olmaksızın

7 Mustafa Sabri, Mevkifu'l-beşer tahte sultani'l-kader, Çev. İsa Doğan, İstanbul, 1989, s. 313.

8 A.g.e., s. 229.

9 A.g.e., s. $229-230$.

10 A.g.e, s. 234. 
hatta onu ikna ve razı etme yoluyla, süsleme ve sevdirme yoluyla gerçekleşirse, bu durumda Allah kuluna kötü fiilleri de sevdirmiş ve süslemiş olmaz mı? Bu bağlamda yazara göre bir fiilin faili 'yaptığımı bana kötü göstermediler. Aksine beni ikna ve razı ederek ona meylettirdiler' sözüyle kendisinden mesuliyeti kaldırmaz. ${ }^{11}$ Ancak verilen örnekte failin 'yaptığımı bana kötü göstermediler' şeklinde bir ifade kullanması yanlış olur. Çünkü Kur'an'da insanın yaptığı şey ona iyi ve kötü olarak gösterilmektedir.

Hükümdarlar için zorlamadan ve muhtariyeti bozmaktan bahsedildiğinden yazara göre ikna ve razı etme yoluyla kulun iradesinin Allah tarafından meylettirilmesine zorlama denilemez. Manevî cebirle ihtiyar birbirini yok etseydi, mecbur edenin cebri mecburun iradesiyle çelişirdi. İşte bu çelişkiden dolayı muhtariyeti bozana hakiki cebir denmektedir. ${ }^{12}$ Ancak mesele bu şekilde tek yönlü olarak ele alınmış olmaktadır. Zira insan açısından hakiki cebirden bahsedilerek, manevî cebrin hakiki cebir olmadığı dolayısıyla insanın muhtariyeti ile çelişmeyeceği ifade edilmek istenmektedir. Fakat meseleye bir de Allah'ı nazar-1 dikkate alarak bakarsak, Allah'ın iradesinin kulun iradesini isterse süsleme ve sevdirme yoluyla olsun mutlak mânâda etkilemesine de hakiki cebir diyebiliriz. Böyle bir cebir de muhtariyetibozduğundan bu iki şeyi uzlaştırmak mümkün olmaz.

Yazar, cebirle mesuliyeti uzlaştırma hususunda şöyle demektedir. Biz, Allah'ın meşiyyetine tâbi oldukları için kulların fiillerinde mecbur olmalarını, onların mesul olmalarıyla uzlaştırmaktan aciz olsak bile, Allah böyle bir uzlaştırmadan aciz değildir. ${ }^{13}$ Ancak böyle bir ifadeyi anlamak zordur. Zira yazar, bir taraftan probleme çözüm getiriyor diğer taraftan da insanın acziyetinden bahsederek Allah'ın böyle bir uzlaştırmadan aciz olmadığını söylüyor.

Mustafa Sabri'ye göre kader probleminde hem Allah ile ilgili yön hem kul ile ilgili yön birlikte ele alınmalıdır. Yani bu yönlerden birisi ihmal edilmemelidir. Meselâ Allah ile ilgili yön ihmal edilerek insana irade verilse ve Allah'ın iradesi onun iradesine tâbi olsa böyle bir tefviz (havale), Allah'ın izniyle olsa bile insan için çok fazladır. Zira bu, âlemde pek çok hadisenin Allah ile irtibatını kesmek anlamına gelir. Bu durumda hadiselerin beşer iradesine tâbi olan Allah'ın iradesine bağlanmasının hiçbir önemi yoktur. ${ }^{14}$ Ancak burada problemli bir durum vardır. Zira Allah'ın iradesi, insanın iradesine tâbi olduğunda böyle bir durum âlemde pek çok hadisenin Allah ile irtibatını kesmek anlamına geliyorsa ve böylece hadiselerin beşer iradesi-

11 A.y.

12 A.g.e., s. 235.

13 A.g.e., s. 240.

14 A.g.e., s. 241. 
ne tâbi olan Allah'ın iradesine bağlanmasının hiçbir önemi olmuyorsa aynı şey insan iradesinin Allah'ın iradesine tâbi olması halinde niçin söz konusu olmasın? Böyle bir durumda muhtariyetten ve mesuliyetten bahsedilebilir mi? Ayrıca yazara göre, Allah'ın meşiyyetinin insanın meşiyyetine tâbi olduğunu kabul etmekle, bu meşiyyeti inkâr etmek arasında hiçbir mânâ farkı yoktur. Zira Allah, "Allah dilemedikçe siz dilemezsiniz" diyor da "siz dilemedikçe Allah dilemez' demiyor. Madem ki 'siz dilemedikçe Allah dilemez' dendiğinde böyle bir ifade Allah'ın meşiyyetinin inkârı anlamına geliyorsa, "Allah dilemedikçe siz dilemezsiniz" ifadesi de insanın meşiyyetinin inkârı anlamına gelmelidir.

Yazar, manevî cebri hakiki cebirden daha kuvvetli görme babında şöyle der: Allah kullarını yapmalarını dilediği fiille zorlamaz. Sadece fiilin sebebini onların kalplerinde yaratmak suretiyle onları ikna ve teşvik eder. Bu teşvik ve iknanın derecesi, zorlamadan daha kuvvetli olmak üzere karşı çıkılamayacak bir şekildedir. ${ }^{15}$ Yani bu teşvik ve ikna cebirden daha kuvvetli ve daha tesirlidir. Ancak yazar, teşvik ve iknayı yani manevî cebri, hakiki cebirden daha kuvvetli ve tesirli olarak ifade ederken başka bir yerde manevî cebirle hakiki cebri ayırarak insanın sorumluluğu karşısına manevî cebri koymak suretiyle bunların çelişki oluşturmadıklarını söylüyordu. Fakat manevî cebir, hakiki cebirden daha kuvvetliyse manevî cebir ile insanın sorumluluğunu uzlaştırmak zordur.

Allah'ın kullarına hidayet vermesinin ve onları saptırmasının, kulların geçmişte hak edişlerine bağlı olduğuna delâlet eden birtakım ayetlerin Kur'an'da olduğu söyleniyor. Bu tür ayetlerden hareketle Allah'ın hidayetinin ve saptırmasının kulların hak edişlerine bağlı olduğunu söyleyenlere Mustafa Sabri şöyle cevap verir: Bazı ayetler, Allah'ın hidayetinin ve saptırmasının sebeplerinin kullar tarafından oluşturulduğunu ifade etse bile, sebepten bahsetmeyen ayetler, sebepleri ihtiva eden ayetlerden daha fazladır. Bu bakımdan sebepleri ihtiva etmeyen ayetleri, sebeplerin bulunduğu ayetlere hamletmek zordur. ${ }^{16}$ Ancak buna şöyle itiraz edilebilir: Bu iki grup ayet birbirine hamledilemez. Zira her iki grup ayetin anlamı birbirinden farklıdır. Ayrıca sayıca çok olanın sayıca az olana hamledilmesi zorsa, bu durum, sayıca az olanın sayıca çok olana hamledilmesini gerektirebilir. Bu takdirde de cebir gerekli olur. Cebirle muhtariyeti uzlaştırmak ise zordur.

Buraya kadar iki Türk kelâmcının kader konusundaki görüşlerine ve ortaya çıkan problemli durumlara kısaca değinmiş olduk. Bu problemli du-

15 A.g.e., s. 208.

16 A.g.e., s. 167-169. 
rumlar meseleye belli bir tür akılcıllk ve bu doğrultuda oluşturulan sistem çerçevesinde çözümler ortaya koymaktan kaynaklanmaktadır. O halde belli bir tür akılcılığa ve buna göre oluşturulan sisteme bağlı kalmadan kader problemine çözüm getirmek gerekir. Bu da kader konusunu meselâ anlambilim açısından değerlendirmekle mümkün olabilir.

Kader problemine belli bir tür akılcılık doğrultusunda çözüm gerektirildiğinden bahsederken bu tür akılcıllğın kelâm açısından soyut karakterli akılcılık olduğu söylenebilir. Zira kelâmcılar kaderin insan fiiliyle bağlantısını göz önüne alarak ona çözüm getirmeye çalışıyorlar. Fiil ise soyut karakterli bir şeydir. Dolayısıyla kader problemine getirilen çözümde soyut karakterli akılcılık kullanılacaktır. Bu tür soyut karakterli akılcılığa göre oluşturulan çözümlerde yukarıda geçtiği üzere birtakım olumsuzluklar olabildiği gibi, bu çözümlerde kullanılan ayetlere bağlamla uygun olmayan anlamlar verilebilmekte ve ayetler yanlış bir şekilde delil olarak kullanılabilmektedir. Benzer olumsuzluklar selefîler (hadisçiler) tarafindan kullanılan somut karakterli akılcılıkta da ortaya çıkmaktadır. O halde bu tür olumsuzlukların söz konusu olmaması için kader konusunun anlambilim açısından değerlendirilmesi faydalı olabilir. Kader konusunu anlambilime göre değerlendirmek, kader kelimesi ile müştaklarının belli bir metinde -ki bu Kur'an metnidir- anlamlarını tespit etmek ve bu anlamların belli bir tür akılcılığa göre oluşturulan çözümlerden farklılı̆̆ını göstermek demektir.

Kader konusunun belli bir tür akılcılığa göre anlaşılması ile anlambilime göre anlaşılması arasında mahiyet farklılığı vardır. Zira birincisinde hareket noktası belli bir tür akılcılık iken ikincisinde ise hareket noktası dildir (dilsel birimlerdir). Belli bir tür akılc1lıktan hareket etmek, buna uygun bir varlık anlayışının ortaya konulmasını gerektirir. Yani akılcılık ve varlık anlayışları arasında karakter bakımından (somut ve soyut karakterlilik bakımından) uygunluk söz konusu olduğu gibi, akılcılığın varlık anlayışını gerektirmesi durumu da söz konusudur. Buna mukabil dilden hareket etmek, dilsel birimleri anlambilim kriterlerine göre anlamak demektir. Dolayısıyla aklî yaklaşımlarla dilsel yaklaşımları birbirinden ayırmak gerekir.

Keza her ne kadar dilsel ifadeler kullanılsa da analitik felsefe ile anlambilim arasında da farklılık vardır. Analitik felsefede dil analizi belli bir tür akılcılık ve varlık anlayışı çerçevesinde yapılır. Örneğin mantıksal atomculuğa göre dil, düşüncenin ve onun yöneldiği dış dünyanın görüntüsüdür. ${ }^{17}$

17 İhsan Turgut, Russell ve Wittgenstein'da Mantıksal Atomculuk, (Basılmamış Doktora Tezi), Ankara Üniversitesi i̇lâhiyat Fakültesi, 1978, s. 83. 
Atomik önermelerin tek ve belirli olan somut bir anlamı vardır. Yani bir kelimenin anlamı bir önermede gösterdiği nesnedir. Bir başka ifade ile atomik bir önermeyi oluşturan kelimeler, gösterdikleri şeyler bakımından anlam kazanırlar. Bu durumda dinî ve metafizikî önermeler, olgusal olmadıkları için önerme sayılmazlar. Dolayısıyla bu tip önermelerin analizleri mümkün değildir. ${ }^{18}$ Buna karşın anlambilimde dilsel ifadelerin kullanılması, dinî, metafizikî ve olgusal ayırımı yapmadan dilden hareket etmek ve anlambilimsel kriterlere göre dilsel ifadelerin anlamlarının tespit edilmesi demektir. Dolayısıyla dilsel ifade ile anlam arasında (meselâ sözcük ile anlam arasında) sıkı bir ilişki vardır. Bu durumda anlam konusunda sözcükten hareket etmek ve çeşitli anlamları ona bağlı olarak açıklamak yanlış olmayacaktır.

Biraz da anlamın ne olduğu üzerinde duralım. Dile özgü soyutlamayla yansitılan kavrama anlam denilmektedir. Meselâ 'balık' sözcügüü, yüzen birtakım varlıkların ortak niteliklerine dayanan dile özgü soyutlamadır. Bu soyutlamayla yansitılan kavrama anlam diyebiliriz. Bu durumda kavramlar, sözcüğe sıkı sıkıya bağlı, dilbirliği olan kimselerdeki ortak genel tasavvurlar olmaktadır. ${ }^{19}$ Burada kavram, 'anlam' anlamında kullanılmıştır. Dolayısıyla bu anlamdaki kavram ile mantıkta söz konusu edilen kavram arasında farklılık vardır. Mantıkta kavram, birşeyin tasavvuru (düşüncesi) olması açısından göz önünde bulundurulur.Dolayısıyla kavramın dilsel işareti olan 'terim'in mantıkta bir önemi yoktur. Halbuki anlam ile ilgili olarak söz konusu edilen kavram, sözcüğün anlamıdır ve sözcükle anlam arasında sıkı bir ilişki olduğundan hem sözcüğün hem de anlamın önemi vardır. Buradan 'sözcük' ile 'terim'in farklı şeyler olduğu ortaya çıkmaktadır. Terim, isim olarak yalın halde, fiil olarak da mastar halindedir. Örneğin 'masa' ve 'görmek' birer terimdir. Sözcük ise dil içinde yalın halde, -i halinde ve diğer hallerde bulunabildiği gibi, edat, zamir ve sıfat olarak da bulunabilir. Örneğin 'masada' ve 'görüyorsun' birer sözcüktür. ${ }^{20} \mathrm{Bu}$ açıllamalar bize her yapıdaki sözcüğün farklı bir anlamından bahsedilebileceğini gösterir.

Anlamın oluşmasında her yapıdaki sözcüğün önemli bir işlevi olduğu gibi, bağlamın da önemli bir rolü vardır. O halde bağlamdan kısaca bahsetmek yararlı olacaktır. XX. yüzyıldaki dilbilim akımlarından yapısalcılık, dili tek tek değerler olarak değil, birbiriyle sıkı değerlerden kurulmuş bir bütün olarak kabul etmektedir. Dolayısıyla kelimeyi öteki öğelerden ayırmaya, onlarla olan bağlarından koparmaya imkân yoktur. Böylece yapısalcılık akı-

18 A.g.e., s. 72.

19 Doğan Aksan, Her Yönüyle Dil, I-III, Ankara 1977, III, 180.

20 Doğan Özlem, Mantık, İstanbul, 1991, s. 57-58. 
mı, sözcüklerin dilde bağlama göre değer kazandığını gösterir. Meselâ 'çocuk' sözcügüü bilinen belli bir kavramı yansıtır. Eğer 'çocuk askere gitti' denirse burada anlatılmak istenen yetişkin bir insandır. Ama 'çocuk biberonu emip bitirdi' cümlesinde ise anlatılmak istenen süt bebeğidir. Diğer taraftan 'çocuk ilkokulun üçünde' cümlesinde ise çocukluk çağındaki insan anlatılmaktadır. ${ }^{21}$

Dilbilimin eski dönemlerinde bazı bilginlerce sözcükler, içine anlamların konduğu boş kutular olarak düşünülmüştür. ${ }^{22} \mathrm{Bu}$, şu anlama gelir: Belli sözcüklerin belli anlamları vardır. Yani sözcüklere türemiş halde olmaları ve bağlamları göz önüne alınmadan belli anlamlar yüklenmiştir. Halbuki anlambilime göre bir sözcüğün anlamını belirlerken, o sözcüğün türemiş biçimlerini ve bağlamını göz önünde bulundurarak kazanmış olduğu anlamları tespit etmek gerekir.

Bağlamı oluşturan öğelerin bir bölümü dil-içi, bir bölümü de dil-dışı özellikler taşırlar. Örneğin kullanılan dille ilgili tüm özellikler ve metin içindeki dilsel birimlerin birbiriyle kurduğu karşıllkklı ilişkiler ve benzerleri dil-içi öğeler, katılımcıların dünya bilgisi, bireysel özellikleri, yer ve zaman dil-dışı öğelerdir. ${ }^{23}$ Dil-içi bağlamla ilgili olarak aşağıdaki iki cümleyi göz önüne alalim:

1. Güzel Nihal zulme boyun eğmedi

2. Nihal güzel konuşuyordu.

'Güzel' sözcüğü (1)'de sıfat, (2)'de ise zarf olarak görev yapmaktadır. Çünkü 'güzel' sözcüğü bu cümlelerde farklı türden sözcükleri nitelemektedir. 'Güzel' sözcügüü (1)'de Nihal'i (2)'de ise konuşmayı (eylemi) nitelemektedir. Bu da dildeki birimlerin öncelikle birlikte kullanıldığı birimlerle kurdukları ilişkilere göre anlam kazandığını gösterir. ${ }^{24}$

Dil-dışı bağlamla ilgili olarak da aşağıdaki iki örneği göz önüne alalım.

1. Öğrenci kantininde bir öğrenci, diğerine yanında duran boş sandalyeyi göstererek sorar:

- Dolu mu?

- Dolu.

2. Sinema gişesinde bilet satıcısı, filmi izlemek üzere bilet almak isteyen izleyiciye şöyle der:

21 Doğan Aksan, Her Yönüyle Dil, III, 201.

22 A.g.e., III, 202

23 Selçuk İşsever, Türkçe Metinlerdeki Bağlantı Öğelerinin Metinbilim ve Kullanımbilim Açısından Ișlevleri, (Basılmamış Yüksek Lisans Tezi), Ankara Üniversitesi Sosyal Bilimler Enstitüsü, 1995, s. 16.

24 İlknur Keçik - Leyla Subaşı Uzun, Türkçe Sözlü ve Yazılı Anlatım, Anadolu Üniversitesi Açıköğretim Fakültesi Yayınları, Eskişehir, 2003, s. 5. 
- Dolu...

'Dolu' sözcüğü her iki örnekte de farklı bir anlamı aktarmaktadır. 'Dolu' sözcüğ̈ü örnek (1)'de kantinde oturmak için yer arayan bir öğrenciye burada oturan olacak, buraya oturamazsınız demek isteyen bir diğer öğrenci tarafından kullanılmıștır. Örnek (2)'de ise 'dolu' sözcüğü, sinemada filmi izlemek isteyen kişiye biletin kalmadığı bilet satıcısı tarafından aktarılmaktadır. 'Dolu' sözcüğündeki anlam farklılaşmasına yukarıdaki örneklerde olduğu gibi, dilin birimlerinin birbiriyle kurdukları ilişkiyi neden olarak gösteremeyiz. Çünkü örneklerin her birindeki ‘dolu’ sözcügüü, söze dökülmüş tek dilsel birimdir. Dolayısıyla bu sözcügüün anlamındaki değişmeyi ortaya çıkaran, bu sözcüğün kullanıldığı durumlar ve buna bağlı olarak belirginleşen kullanım amaçlarıdır. ${ }^{25}$

Buraya kadar anlatılanlar çerçevesinde kader konusuna anlambilim aç1sından çözüm getirmek istediğimizde, kader kelimesi ve müştaklarının Kur'an metninde bağlama göre kazandığı anlamları tespit etmek ve belli bir tür akılcılığa göre oluşturulan çözümlerden farklılıklarını göstermek gerekmektedir. Kader kelimesinin temel anlamını 'güç yetirmek' olarak almamız gerekiyor. Böylece diğer anlamları (yan anlamları), bu temel anlama göre açıklamak mümkün olacaktır. Kader kelimesinin temel anlamılla ilgili olarak Mülk Sûresi birinci ayet örnek olarak verilebilir: "Egemenlik elinde olan Allah yücedir ve O'nun her şeye gücü yeter." Ayette kader 'güç yetirmek' anlamındadır. Zira mülk sahibi olmakla güç yetirmek arasında bir ilgi vardır. Mülk elinde olanın her şeye gücü yeter. Kur'an'da kader kelimesinin bu anlamda kullanışı ile ilgili birçok örnek vardır. Ancak biz bununla yetinmek istiyoruz. Kader kelimesinin güç yetirme olan temel anlamıyla ilgili bir başka anlamını Talâk Sûresi 7. ayette bulmaktayız. Ayetin mânâsı şöyledir: "Genişlik sahibi kimse nafakayı genişliğine göre versin. Rızkı daraltılan kimse, Allah'n kendisine verdiğinden versin. Allah bir kimseyi ancak verdiği ile mükellef kılar. Allah, zorluktan sonra kolaylık kılacaktır." Kader kelimesi ayette rızkın daraltılması anlamına gelmektedir. Zira bir kimseye rızkın güç yetirilmesi, rızkın o kimseye belli bir ölçü ile verilmesi, yani ölçüsüz bol bir şekilde verilmediği anlamına gelir. Dolayısıyla rızık o kimse için daraltılmış (kısılmış) olmaktadır. Ayrıca ayetin baș tarafının (genişlik sahibi kimse nafakayı genişliğine göre versin) kader kelimesinin anlamının 'bir kimsenin rızkının daraltılması' olarak anlaşılmasında rolü vardır. Çünkü ayetin baş tarafındaki ifade ile ondan sonra gelen ifade birbiriyle ters anlamlıdır. Bi- 
rinci kısımda 'imkânı geniş olma' durumu söz konusu olduğuna göre ikinci kısımda 'imkânı geniş olmama' yani 'rızkın daraltılması' durumu söz konusu olacaktır.

En'âm Sûresi 96. ayet: "Tan yerini ağartandır. Geceyi kendisiyle sükûnet bulunan şey, güneşi ve ayı hesaplama kılan O'dur. Bu, yüce olanın ve bilenin takdiridir." Ayette Allah'ın takdiri, Allah'ın geceyi kendisiyle sükûnet bulunan şey, güneşi ve ayı hesaplama kılması anlamına gelmektedir. Ayetteki takdir kelimesi, fa'ale kalıbının masdarıdır. Herhangi bir fiil bu kalıba aktarılarak iki nesneye geçişli (ettirgen) kılınmaktadır. Ayette ce'ale fiili iki nesneye geçişli olarak kullanılmıştır. Meselâ gecenin, kendisiyle sükûnet bulunulan şey kılınması gibi. İşte fa'ale kalıbındaki takdir kelimesi de bu anlamı (bir şeyin bir şey olarak kılınması anlamını) ifade etmiş oluyor.

En'âm Sûresi 91. ayette kader kelimesi değerlendirmek anlamına gelmektedir. Ayetin anlamı şöyledir: "Allah, hiçbir insana bir şey indirmedi demekle Allah'ı gereği gibi değerlendirmediler." Ayette kader kelimesine bu anlamın verilmesinde inanmayanların 'Allah, hiçbir insana bir şey indirmedi' şeklindeki sözlerinin rolü vardır. Böyle bir ifade bir yargıda bulunmak, yani değerlendirmek anlamina gelmektedir.

Kader kelimesinin bir işi planlamak anlamı, Kamer Sûresi 10-12. ayetlerde söz konusudur. Ayetlerin anlamı şöyledir: "O, ben yenildim. Bana yardım et diye Rabbine yalvardı. Biz de gögü̈n kapılarını boşalan sularla açtık. Yeryüzünde kaynaklar fişkırttık. Her iki su planlanan bir işe göre birleşti.” Her iki suyun (gökten inen su ile yerden fışkıran su) güç yetirilen bir iş üzere birleşmesi demek, planlanan bir iş üzerine birleşmeleri anlamına gelmektedir.

Âl-i İmran Sûresi 29. ayette kader kelimesi, Allah'ın bilmesi anlamına gelmektedir. Ayetin anlamı şöyledir: "De ki içinizde olanı gizleseniz de, açıklasanız da Allah onu bilir. Göklerde ve yerde olanı bilir. Allah'ın gücü her şeye yeter." Ayette önce Allah'ın insanların içinde olanla göklerde ve yerde ola$\mathrm{n} ı$ bildiğinden daha sonra da Allah'ın her şeye gücünün yettiğinden bahsedilmektedir. Dolayısıyla bu iki durum arasında ilgi vardır. Böylece Allah'ın her şeye güç yetirmesi içerisinde, başka şeyler olduğu gibi bunlardan birisi olan Allah'ın insanların içindekini bilmesi ile göklerde ve yerde olanı bilmesi vardır.

Hadîd Sûresi 22. ve 23. ayetlerde Allah'in musibeti yazmasından bahsedilmiştir. Ayetlerin anlamı şöyledir: "Yeryüzünde ve kendinizde size isabet eden bir şeyi yaratmamızdan önce o, bir kitaptadır. Bu, Allah'a kolaydır. Kaybettiğinize üzülmemeniz ve Allah'ın size verdikleriyle şımarmamanı içindir. Allah kendini beğenen ve övünen hiç kimseyi sevmez." Kader meselesinde çok kullanılan bu ayetlerdeki bir musibetin bir kitapta bulunması (Allah'ın yaz- 
mas1), insana isabet eden iyi ve kötü musibetle ilgili olup, insan fiiliyle ilgili değildir. Ayrıca ikinci ayette Allah, isabet eden musibetin yaratılmadan önce bir kitapta olmasının nedenini insanın kaybettiklerine üzülmemesi ve Allah'ın verdikleriyle şımarmaması için diye açıklar. Prof.Dr.Hüseyin Atay'ın belirttiği gibi Allah, mü’minleri ümitsizliğe düşmemeleri için teselli etmiş ve böbürlenip yollarını şaşırmaktan onları korumuştur. ${ }^{26}$ Yoksa birinci ayet, insanın fiili ile ilgili olarak daha önceden yazılmış bir kadere uymak zorunda kalındığını ifade etmemektedir.

Diğer taraftan Âl-i İmran Sûresi 165. ayette kader kelimesi, musibeti isabet ettirmek anlamına gelmektedir. Ayetin anlamı şöyledir: "Başkalarını iki misline uğrattı̆̆ını musibet kendinize geldiğinde bu, nereden dersiniz. De ki: o, kendinizdendir. Allah'ın gücü her şeye yeter." Allah'ın her şeye güç yetirmesi içinde Allah'ın insana musibeti isabet ettirmesi de vardır.Dolayısıyla kader kelimesi, Allah'ın musibeti yazması ve musibeti isabet ettirmesi anlamlarına da gelmektedir. Kader kelimesinin bu iki anlamının da insan fiiliyle bir ilgisi yoktur.

Kader kelimesinin zikrettiğimiz son iki anlamıyla Allah'a iman arasında bir ilgi vardır. Bu bağlamda Tegâbun Sûresi 11. ayet zikredilebilir. Ayetin mânâsı şöyledir: "Bir musibet ancak Allah'tn izniyle isabet eder. Kim Allah'a inanirsa, Allah onun kalbine hidayet verir. Allah her şeyi bilendir." Ayette önce bir musibetin Allah'ın izni ile isabet etmesinden sonra da Allah'a iman edenin kalbine Allah'ın hidayet vermesinden bahsedilmektedir. Bu iki kısım arasında bağlantı kurarak musibetin Allah'ın izni ile isabet etmesinin Allah'a iman ile ilgili olduğunu söyleyebiliriz. Bu durumda Cibril hadisinde geçen iyi ve kötü kadere iman, iyi ve kötü musibetin Allah tarafından yazılmasına ve isabet ettirilmesine iman şeklinde anlaşılabilir. Yoksa kaderin insan fiili ve bunun ezelde tespitiyle bir alâkası yoktur. Zaten kader kelimesi ile Kur'an'da insan fiilinin kastedilmiş olması, Kur'an'ın uslûbuna da aykırıdır. Zira kader kelimesi ile insan fiilinin kastedilmiş olunması, insan fiiline ayrı bir varlık kategorisi vererek, insan fiilini somut karakterli bir tarzda müstakil bir varlıkmış gibi değerlendirmek anlamına gelir. Halbuki fiil, insana bağlı olarak anlaşılan soyut karakterli bir şeydir. Dolayısıyla kader kelimesi ile Kur'an'da insan fiili kastedilmiş olunamaz. Öte yandan kadere imanın bir iman esası olarak kabul edilip edilmemesi, iman esasları anlayışı ile ilgilidir ki, onu da diğer bir yazımızda ele aldık. 